\title{
Traveller's Empowerment: Travelling Website Service Quality, Attitude towards UGC and Booking Intentions of Travellers
}

\begin{abstract}
Noreen Zahra ${ }^{1}$, Ayesha Qayyum², Yasir Rashid ${ }^{3}$
Abstract

The word of mouth is known to be the best resource for a traveller. For years, travelling companies are finding ways to promote review and user generated content to attract more future travellers. The Web 2.0 which is referred as next generation of the Internet characterized by the dynamic user-generated content facilitates users to create and share content and in consequence travellers are more empowered. This technological breakthrough has transformed customers into participative agents. The Travel Eु Tourism industry has been seriously challenged by Web 2.0 where travel customers are browsing websites for travel planning and hotel booking. Such travel agency websites provide information and booking facilities and travel customers also share their experiences, pictures and advice known as User-Generated Content (UGC). The same trend is approaching Pakistan having an immense potential for online travel companies. Travel $\mathbb{E}$ Tourism industry of Pakistan is experiencing a thriving growth since the terror attacks have reduced exponentially hence qualify for a scholarly attention. This study explores the effects of website quality of travel agencies through E-SERQUAL on the attitude of Pakistani travel customers towards UGC and hotel booking. It is a survey-based quantitative study. The data is collected through questionnaires from university 339 students and Structural Equation Modelling (SEM) is used to provide insights into Pakistani customers' attitude and behavior towards booking intentions. It is established that unlike other countries, Pakistani travellers are least concerned about website safety and security whereas website functionality, information content and quality are leading factors affecting attitude towards UGC followed by website appearance and presentation. It is concluded that website service quality plays a major role in adoption of UGC that directly affects the hotel booking intentions of travel customers.
\end{abstract}

Keywords: User Generated Content (UGC), ESERVQUAL, Web 2.0, website quality, hotel booking intentions

1 Assistant Professor, Management Science Department Virtual University of Pakistan.

Email: noreenzahra@vu.edu.pk

2 Assistant Professor, Marketing Department University of Management and Technology.

3 Assistant Professor, Acting Chairperson Department of Marketing, Marketing Department University of Management and Technology.

\begin{tabular}{|c|c|}
\hline ARTICLE HISTORY & \\
\hline 09 May, 2018 Submission Received & 01 Oct, 2018 First Review \\
\hline 04 Feb, 2019 Second Review & 11 May, 2019 Third Review \\
\hline
\end{tabular}

25 Jun, 2019 Accepted 


\section{Introduction}

The world has experienced an exponential growth in Web 2.0 applications that have empowered the internet-users to create, and post their content and other internet-users can view and respond (Constantinides \& Fountain, 2008). Web 2.0 is referred as next generation of the internet characterized by the dynamic user-generated content as opposed to static web pages. Web 2.0 is associated with the emergence of social media where users experience participation in the networks (Harris \& Rea, 2019; Newman, Chang, Walters, \& Wills, 2016). Internet World Stats indicated the internet users around the globe up to 4.05 billion till 2017 and only Asia region has 1.99 billion internet users. Multiple studies have identified the unprecedented adoption of Web 2.0 applications by millennials that open new research avenues for scholars and practitioner (Bodewes, 2016; Constantinides \& Fountain, 2008; Cox, Burgess, Sellitto, \& Buultjens, 2009). This overwhelming and persistent expansion of technology has transformed the travel and tourism industry while making it more information intensive, and competitive. Now, travellers are exposed to travelling company's websites like Booking.com, Expedia.com, and Tripadvisor.com while having networks with peer-to-peer virtual communities with a massive amount of User Generated Content (UGC) (Chung \& Buhalis, 2008; Xiang \& Gretzel, 2010; Huang, Goo, Nam, \& Yoo, 2017). These travelling company's websites provide travel advisory and information regarding hotels, restaurants, flights, deals, and road trips which are known as Agency Generated Content (AGC). It is acknowledged in the latest research work and among practitioners that technology has drastically transformed the means by which customers plan and select hotels (Huang, Goo, Nam, \& Yoo, 2017; Sun, Cárdenas, \& Harrill, 2016). The empirical evidence can be traced from Statista ${ }^{4}$ revealing the fact that digital travel sales around the globe have reached up to 564.87 billion U.S. dollars and it exhibits the online travel industry exponential growth in recent years supported by Web 2.0 revolution. Likewise, many leading publishers have launched dedicated journals for travel and tourism industry with leading themes of consumer behavior and use of technology in the tourism industry. For an enriched understanding of the intense travel customers' traffic, and behavior on online travel companies, it is imperative to apprehend the website quality of such websites as travel customers interact and generate content on such websites.

Pakistan, which falls in the region of Asia, is no exception to the usage of the travelling websites. Pakistan has a huge travel and tourism industry. According to statistics of World Travel Tourism Council, the Travel \& Tourism industry of Pakistan is contributing 7.6 billion US Dollars in GDP of Pakistan which constitute 27\% of total GDP. Travel \& Tourism industry supports 2.3\% employee engagement out

4 https:/ www.statista.com/statistics/194133/cybercrime-rate-in-selected-countries/ 
of total employment and Pakistan Tourism department received USD 100 million investment in recent years (Tribune, 2019). The industry growth starts thriving since the terror attacks have reduced exponentially and tourist traffic observed tripled since 2013 (Kay, 2017). The local online travelling companies e.g. Checkin.pk, Travelstart. pk, and Findmyadventure.pk are capturing the travel and tourism industry digitally. The global companies like Booking.com, Tripadvisor.com and many leading online travelling companies are also operating in Pakistan and giving very intense competition to local travelling companies. Multiple studies are under progression in different regions to explore the customer's apprehension before and during travel planning. Aforesaid statistics about internet usage and Travel \& Tourism industry of Pakistan instigate the attraction of global and local online travelling companies in Pakistan thus the practical significance of empirical studies investigating the website quality, attitude of travel customers towards UGC and, hotel booking behavioral intentions cannot be denied. So far, this area is least explored in the context of Pakistan and this study serves to fill this gap.

To date, the concern of online travelling company's website quality, UGC, reviews credibility, the traveller's preference, booking intentions, and behavior towards the adoption of online travelling websites have become the leading trend among scholars and journals (Abou-Shouk \& Khalifa, 2017; Agag \& El-Masry, 2017). The service quality dimensions (SERVQUAL) are proposed by Parasuraman, Zeithaml, and Berry (1994) but online service quality dimensions are dissimilar to a certain extent. It is imperative to investigate the electronic service quality (E-SERVQUAL) for measuring the traveller's experience with online travelling companies before investigating the attitude towards UGC and hotel booking behavior. In comparison to physical travel agent company, online travelling companies' lacks live human interaction and tend to be more impersonal, anonymous and automated. E-SERVQUAL defines the website service that enables the efficient, secured and error-free usage and booking experience (Parasuraman, Zeithaml, \& Malhotra, 2005). E-SERVQUAL is also defined as judgment, experience and overall satisfaction with a value proposition of online company's web space (Santos, 2003). For the underlying study, the constructs adapted to measure the online travelling company's website are (1) web functionality, (2) information content and quality, (3) safety and security and, (4) appearance and presentation (Fu Tsang, Lai, \& Law, 2010). The overall judgment and experience with online travelling company's website expedite the attitude of writing and reading reviews on such websites. The user-generated content (UGC) is defined as text, audio, video and image content created and produced by internet users without any professional involvement (Daugherty, Eastin, \& Bright, 2008). The most frequently used theory for explaining attitude and behavior is Theory of Planned Behavior which states attitude as a person's favourable or unfavourable judgement towards a certain 
phenomenon and behavior is an outcome that is observable (Madden, Ellen, \& Ajzen, 1992; Netemeyer, Ryn, \& Ajzen, 1991). For the underlying study, the attitude is the positive or negative judgement of UGC and behavior is an outcome for hotel booking on such websites. The online travelling companies are claiming popularity and credibility while propagating the volume of UGC, but it is of least value if the attitude of travel customers towards UGC as the credible source is not established. It is significant for scholars and practitioners to investigate the worth of UGC available on online travelling company websites for positive attitude and behaviors towards booking intentions in the context of Pakistan travel and tourism. This study aims at filling this scholarly gap as this empirical investigation aims at measuring and investigating the online travelling company's websites service quality and its role in determining the attitude towards UGC and booking behavior. It also investigates the mediating relationship of attitude towards UGC between websites service quality and booking behavior. The research questions designed for this study are as follows:

Q1: What is the impact of online travelling website service quality on the attitude of travel customers towards User Generated Content (UGC) in Pakistan?

Q2: Does the attitude of Pakistani customers towards User Generated Content (UGC) mediate the relationship between online travelling website service quality and behavioral intentions towards hotel booking?

\section{Literature Review}

\subsection{Service quality measures for websites}

Website service quality is a leading topic in travel and consumer behavior related journals since websites are the service space for travel customers (Razak, Ahmad, \& Marimuthu, 2016). It is evident from recent literature that in travel and tourism, there is the need for more empirical investigations on the impact of website service quality and purchase intentions (Ali, 2016; Dedeke, 2016). Initially, the service quality dimensions were more related to physical and face to face interaction with customer and company in service space. Since its initiation, SERVQUAL has become one of the most frequently used instruments for measuring service quality (Goswami, 2013; Olimpia, Darío, Adriana, Verónica, \& Yolanda, 2016; Parasuraman, Berry, \& Zeithaml, 1991; Parasuraman, Zeithaml, \& Berry, 1985, 1988). Initially, five dimensions of SERVQUAL were presented i.e. tangibility, responsiveness, reliability, assurance and empathy but these dimensions are least applicable to online services thus many studies came with constructs and scale development for online services (Chuang, Chen, Lin, \& Yu, 2016; Jiang, Jun, \& Yang, 2016). Yoo \& Donthu (2001) developed a measurement tool for website quality measurement (SITEQUAL) while 
adding the constructs of ease of use, aesthetic design, processing speed, and security. Madu and Madu (2002) designed an instrument for e-quality adding comprehensive dimensions of online service quality considering performance and features, structure and reliability, security and system integrity, differentiation and customization, polices, empathy and, assurance. Loiacono, Watson and Goodhue (2002) identified further online service quality dimensions comprising of information, interaction, design and response time, visual and emotional appeal, innovative, process and substitutability.

The dimensions identified by Loiacono, Watson and Goodhue (2002) are the most comprehensive dimensions in the present literature. Parasuraman, Zeithaml, and Malhotra (2005) also develop a scale for online service quality comprising of efficiency, system availability, fulfilment, and privacy. Kaynama and Black (2000) exclusively develop a measurement tool for online service quality by taking online travelling agencies as a case study while including content, design, personalization, accessibility, feedback, and investigation. Sigala and Sakellaridis (2004) identified multiple dimensions of online service quality for travelling agencies including information, trust, design and visual appeal, interactivity, design, intuitiveness, responsiveness and viable substitute. Bauer, Falk, and Hammerschmidt (2006) conducted a study on service quality during online shopping and empirical data was collected while using the measurement constructs of functionality or design, enjoyment, process, reliability, and responsiveness. Likewise, Park, Gretzel, and Sirakaya-Turk (2007) conducted a study on online travel companies and develop a measurement tool comprising fulfilment, ease of use, security, information, responsiveness and visual appeal. Most of the dimensions in the multiple studies are overlapping and provide some shared dimensions for measuring website service quality of online travelling companies. For the underlying study, the constructs and measurement items are adapted from a study conducted by Fu Tsang, Lai, and Law (2010) and all adapted constructs and measurement items have shared dimensions supported by the previous literature. It comprises of (1) web functionality, (2) information content and quality, (3) safety and security, and (4) appearance and presentation. The literature support of selected constructs is given in table 1 .

Table 1: Dimensions Adopted for Website Quality

\begin{tabular}{|c|c|}
\hline Dimensions & Literature Support \\
\hline \multirow{2}{*}{ Web functionality } & (Bauer et al., 2006) \\
\cline { 2 - 2 } & (Fu Tsang et al., 2010) \\
\hline Information content and quality & (Loiacono et al., 2002) \\
\cline { 2 - 2 } & (Fu Tsang et al., 2010) \\
\hline
\end{tabular}




\begin{tabular}{|l|c|}
\hline \multirow{2}{*}{ Safety and security } & (Madu \& Madu, 2002) \\
\cline { 2 - 2 } & (Parasuraman et al., 2005) \\
\cline { 2 - 2 } & (Fu Tsang et al., 2010) \\
\cline { 2 - 2 } & (Park et al., 2007) \\
\hline Appearance and presentation & (Park et al., 2007) \\
\cline { 2 - 2 } & (Loiacono et al., 2002) \\
\cline { 2 - 2 } & (Fu Tsang et al., 2010) \\
\hline
\end{tabular}

Note: Literature review summary

\subsection{User generated content (UGC), attitude and behavior}

Till today, with the advent of Web 2.0 applications, consumers are getting fascinating towards internet media and cyber markets thus more and more business models are using the technology and communication support (Constantinides \& Fountain, 2008). The term Web 2.0 is originated by O'Reilly (2005) that describes it as a web platform which is more interactive and provides internet-user to post and share their views in text, images, videos and audios and other internet-users can view and respond. Web 2.0 opens the door for high customer involvement and customers have become new locus of value. The advent of social media e.g. Facebook, YouTube, Twitter, Instagram has provided a cyberspace for creating content i.e. known as User Generated Content (UGC) (Cox et al., 2009). In the online world, UGC is viewed as e-word-of-mouth thus online companies are more concerned about the presence and nature of UGC on their website as word-of-mouth. Though UGC is becoming a source of instigating the consumer demand and adoption behavior (Zhu \& Zhang, 2006) still some schaolrs have different views on UGC and eword-of-mouth. It is mentioned in several studies that UGC has an important implication for online companies with respect to brand loyalty, perceived quality, product and market expansion (Dellarocas, 2003; Nusair, 2016; Susilowati \& Sugandini, 2018). Cheong and Morrison (2013) conducted a study on UGC and Producer-Generated-Content (PGC). Authors first differentiate eWOM from UGC on the grounds that whether the content is generated or conveyed by the user for the public with or without professional intentions. If the user writes a text or captures an image or video without professional intentions, it's UGC whereas if he/she shares the link or already developed content, it's eWOM. Christodoulides, et al (2017) defined UGC as a creative content which is created and produced for public through Web 2.0 media without involving any professional routines or practices.

Later, it is revealed in a study that customers consider UGC more credible as compared to PGC. It is perceived that the content is not controlled by the online 
companies but the highly positive or negative UGC could be harmful to brand image, sustainability, and business expansion. Woodside $\&$ and Lysonski (2008) explained different stages of travel planning including travel desire, information search, alternative evaluations and booking (real purchase) followed by post-purchase evaluation. UGC plays its critical role in the stage of information searching and post-purchase evaluation for UGC creation (writing reviews) (Xiang \& Gretzel, 2010). It is extremely important for all online travelling companies to realize the significance of UGC on their website along with PGC as increasing numbers of travellers are adopting UGC for travel planning (Internet World Stats, 2017). What motivates internet-users to create UGC on online travelling websites is an important question to answer. According to Litvin, Goldsmith, and Pan (2017), travel customers share their experiences, opinion and pictures to facilitate the peers on the travelling website. Research has shown that $88 \%$ of the travellers get influenced by UGC. It is also found that travellers read and review the UGC regarding hotel credibility, location, facilities, cleanliness, and packages (Amaral, Tiago, \& Tiago, 2014; Constantinides \& Fountain, 2008; Cox et al., 2009). The study regarding adoption of technology endorses the adoption of online services in travelling industry (Litvin, Goldsmith, \& Pan, 2008). There are many studies covering the aspect of UGC, its role during travel planning but the vendor provided features i.e. website and its service quality in developing the attitude of travel customers towards UGC is least explored in Pakistani context. Thus, this study aims at exploring the relationship between website service quality of online travelling companies, attitude towards UGC adoption and behavior towards hotel booking among Pakistani travel customers with the following hypotheses:

$\mathrm{H}_{1}$ : Website functionality of travelling company website has a positive impact on attitude towards UGC

$\mathrm{H}_{2}$ : Information content $\&$ quality of travelling company website has a positive impact on attitude towards UGC

$\mathrm{H}_{3}$ : Safety and security of travelling company has a positive impact on attitude towards UGC

$\mathrm{H}_{4}$ : Appearance and presentation of travelling company website has a positive impact on attitude towards UGC

It is yet to be explored that whether the positive attitude towards adoption of UGC is effective in determining the behavior towards real purchase i.e. hotel booking. An empirical examination is required to investigate the travel customer adoption of UGC affecting booking behavior (Sigala, Lockwood, \& Jones, 2001) and this gap with reference to Pakistani consumer is even wider. The relationship between online 
travelling company website service quality and behavior towards hotel booking mediated by the attitude towards adoption of UGC is tested with the following hypothesis:

$\mathrm{H}_{5}$ : The relationship between web functionality, information content \& quality, safety \& security, appearance and presentation and behavior towards hotel booking is mediated through attitude towards UCU

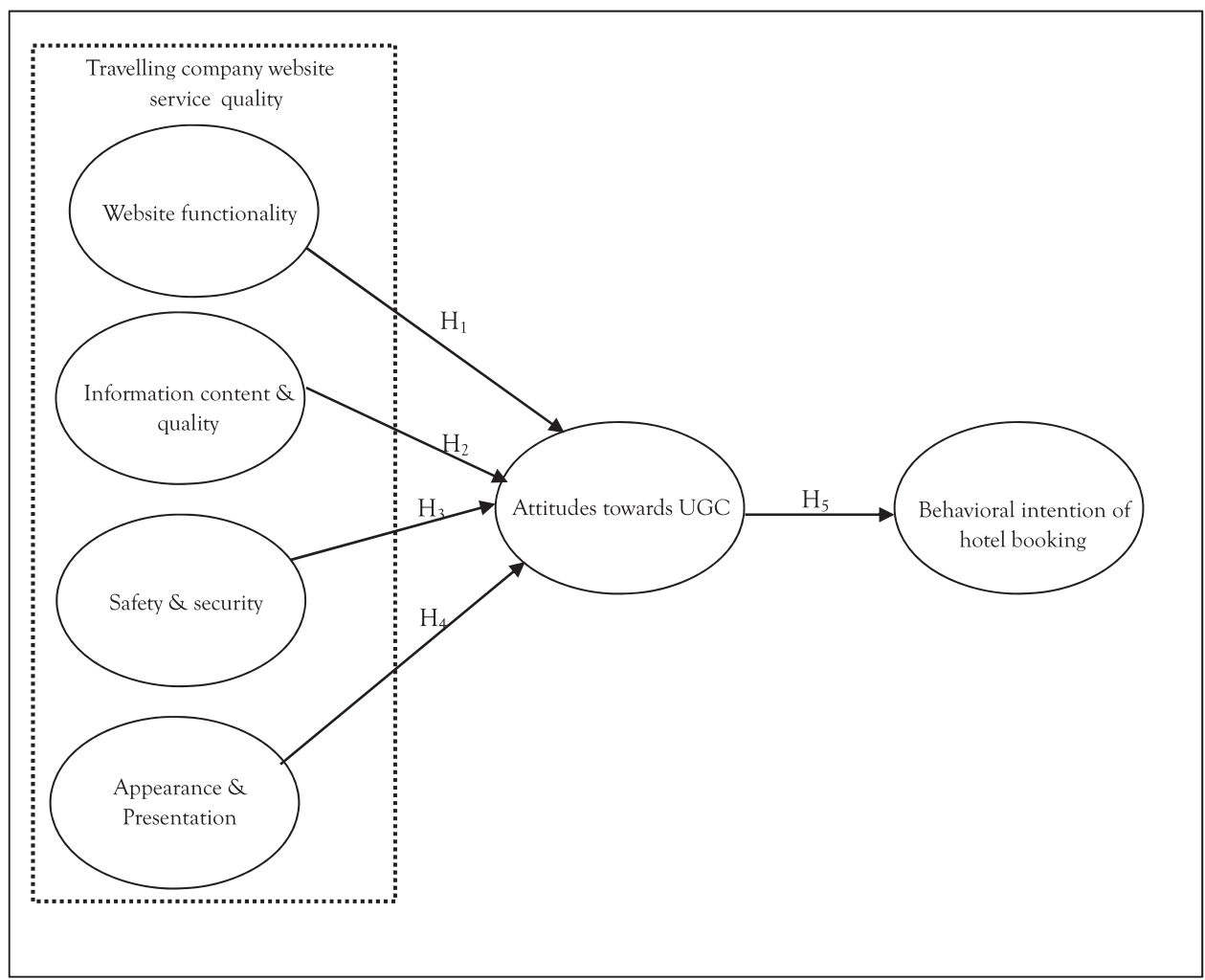

Figure 1: The Theoretical Model

The theoretical model for the study is presented in figure 1.

\section{Research Design}

For the underlying study, the positivist research philosophy was applied. The quantitative approach with field survey was adopted to validate the theoretical framework. It was a cross sectional study. Self-administered questionnaire was used to collect the empirical data on selected constructs including website functionality, information content and quality, safety and security, appearance and presentation of the travelling company website, attitudes towards UGC and behavioral intentions towards hotel 
booking. The data was collected from students enrolled at a private university. The enrolled students were around 17000 . University students seem appropriate for five reasons, (1) they understand the sensitivity of self-administered questionnaire for a research process, (2) most of the students in Pakistan are now travelling abroad for scholarship, research exchange programs and conferences, (3) they are more familiar with web 2.0 applications, and (4) they are concerned travel planner, (5) higher education funded opportunities has increased the desire for international travelling. Many research studies have used students as their representative sample thus same reasoning is adopted while selecting the population frame (Hughes, Wang, \& Shu, 2015; Ladhari \& Michaud, 2015) The sample size determination for Conformity Factor Analysis (CFA) and Structural Equation Modelling (SEM) is very critical. Empirical investigations with simulation studies indicate that with a normally distributed data and no missing values, a sample of 150 is considered as reasonable (Muthén \& Muthén, 2002). In another study, a sample size $\geq 300$ for factor analysis is considered a good sample size (VanVoorhis \& Morgan, 2007). Likewise, for SEM, sample size requirement from 30 to 460 cases is considered as a meaningful (Wolf, Harrington, Clark, \& Miller, 2013). Thus, initially, while following simple random sampling, 460 self-administered questionnaires were distributed, and the response rate was $78 \%$. Out of 358 questionnaires, 339 were considered for the study as remaining questionnaires were incomplete with more than $50 \%$ of missing values. The demographics including gender, age, monthly income, the frequency of travelling and type of travelling are added for understanding the overall profile of the respondents who participated in the study. For said purpose, items were developed with a nominal scale. With reference to frequency of travelling, the categories are developed as rare (one trip in last five years), frequent (at least one trip in a year) and most frequent (more than one trip in a year). Likewise, type of travelling was categorized as, mostly for business, mostly for leisure and mostly for/with family.

\section{Results}

It is imperative to understand the demographic profiles of respondents who participated in the study. It facilitates in interpreting the model, related values, and future directions. The demographic profiles of respondents exhibited in table 2 including age, income per month, the frequency of travelling and type of travelling with frequency and percentage analysis. Table.2 illustrates that out of 339, 294 respondents are below the age of 25 years that constitutes $86.7 \%$ of total respondents. $38(11.2 \%)$ respondents are in the age bracket of $26-35$ years and $4(1.2 \%)$ are in the age bracket of $36-45$ Years. Only 3 respondents are reported above 45 years that constitutes $0.9 \%$ of total respondents thus it is inferred that most of the respondents participated in the study are young and below the age of 25 years. The income per month status 
illustrates that 229 respondents that constitute $67.6 \%$ of total respondents are earning PKR 100,000 per month whereas $84(24.8 \%)$ respondents are earning PKR 100,000300,000 /per month. Likewise, 11(3.2\%) respondents are earning PKR 300,001500,000 /per month and 15(4.4\%) are earning above PKR 500,000/per month. Conclusively, most of the respondents are earning below PKR 100,000-300,000 per month. Frequency and type of travelling are considered as significant demographics as it is more linked to the use of travelling company website and user-generated content (UGC). The frequency of travelling is segregated into rare (one trip in last five years), frequent (at least one trip in a year) and most frequent (more than one trip in a year). The table shows that 123 respondents that constitute $36.3 \%$ of total respondents travel rarely whereas $133(39.2 \%)$ travel frequently. $83(24.5 \%)$ respondents travel more frequently. With respect to the type of travelling, 47(13.9\%) respondents travel for business, $82(24.2 \%)$ travel for individual leisure and a large majority of respondents (61.9\%) travel with family. It is inferred from the table, that most of the respondents

Table 2: Profile of Respondents

\begin{tabular}{|c|c|c|c|}
\hline Demographic & Characteristics & Frequency & Percentage \\
\hline \multirow[t]{4}{*}{ Age } & Below 25 years & 294 & 11.2 \\
\hline & $26-35$ years & 38 & 1.2 \\
\hline & 36-45 Years & 4 & 0.9 \\
\hline & Above 45 Years & 3 & \\
\hline \multirow{4}{*}{$\begin{array}{l}\text { Income (per month in } \\
\text { PKR) }\end{array}$} & Below 100,000 & 229 & 24.8 \\
\hline & 100,000 to 300,000 & 84 & 3.2 \\
\hline & 300,001 to 500,000 & 11 & 4.4 \\
\hline & Above 500,000 & 15 & \\
\hline \multirow[t]{3}{*}{ Frequency of travel } & Rare & 123 & 39.2 \\
\hline & Frequent & 133 & 24.5 \\
\hline & Most frequent & 83 & \\
\hline \multirow[t]{3}{*}{ Type of travelling } & Mostly for business & 47 & 24.2 \\
\hline & Mostly for leisure & 82 & 61.9 \\
\hline & Mostly for/with family & 210 & \\
\hline
\end{tabular}

Sample size $(\mathrm{n})=339$

participated in this study are young; belong to middle-income status, with rare to frequent travelling routines and mostly travel individually or with family.

For measuring the website service quality provided by travelling companies in- 
cluding website functionality, information content and quality, safety and security, appearance and presentation of website, 25 items with 5 Points Likert scale is adapted by a study conducted by Fu Tsang, Lai, and Law (2010). For measuring the attitude towards UGC, 5 items with 5 Points Likert scale is adapted from a study conducted by Cox, Burgess, Sellitto, and Buultjens (2009). For measuring behavior towards booking, 4 items with 5 Points Likert scale are adapted by study conducted by Lien, Wen, Huang, and Wu (2015). For analysis purpose, AMOS V.22 was used as supporting statistical tool. Before conducting CFA, Harman's single-factor test was also applied to diagnose the issue of common variance bias and $28.16 \%$ variance is found because of one signal factor thus conclude that data set is not suffered because of common variance bias (Dedeke, 2016). Before applying SEM on a theoretical model, CFA was conducted for model measurement (model fit), and construct reliability and validity were also calculated. This study used several criteria to determine the inclusion of construct items and the goodness of fit for the model. First, the internal consistency for the reduction is obtained for a meaningful set of factors through Cronbach's coefficient. The values of Kaiser-Meyer-Olkin (KMO) test and of Bartlett's test were also obtained to check the sufficiency of the item numbers for the prediction of selected constructs. It is recommended that $\mathrm{KMO}$ value must be greater than .07 and Bartlett's test must be significant (Leech, Barrett, \& Morgan, 2005) and both assumptions were found satisfied. For internal consistency, the Cronbach's Alpha value is recommended up to .05 but value $>0.7$ is considered as more meaningful (Field, 2009; Hair Jr, Black, Babin, \& Anderson, 2010). For the underlying study, items with Cronbach's Alph value $\geq 0.7$ are selected for the further process. The construct validity $(\mathrm{CR})$ was measured while using the convergent validity that determine the scale item convergence on single contracts and it includes factor loading (at least 0.7), composite reliability (at least 0.8 ) and average extracted variance (at least 0.5 )

Table 3: Convergent Validity

\begin{tabular}{|c|c|c|c|c|c|}
\hline Construct & Items & Factor Loading & Cronbach's Alpha & CR & AVE \\
\hline \multirow{4}{*}{$\begin{array}{c}\text { Web Functionality } \\
\text { (Webf) }\end{array}$} & Webf1 & .822 & .864 & 0.9191 & 0.7409 \\
\cline { 2 - 3 } & Webf2 & .840 & & & \\
\cline { 2 - 3 } & Webf3 & .785 & & & \\
\cline { 2 - 3 } & Webf4 & .983 & .769 & 0.8146 & 0.5944 \\
\hline \multirow{2}{*}{$\begin{array}{c}\text { Information con- } \\
\text { tent and quality } \\
\text { (Infoqual) }\end{array}$} & Infoqual1 & .774 & & & \\
\cline { 2 - 3 } & Infoqual2 & .797 & & & \\
\cline { 2 - 3 } & Infoqual 3 & .741 & & & \\
\hline
\end{tabular}




\begin{tabular}{|c|c|c|c|c|c|}
\hline \multirow{3}{*}{$\begin{array}{l}\text { Safety and security } \\
\text { (Saf\&Sec) }\end{array}$} & Saf\&Sec1 & .827 & \multirow[t]{3}{*}{.738} & \multirow[t]{3}{*}{0.8537} & \multirow[t]{3}{*}{0.6608} \\
\hline & Saf\&Sec2 & .840 & & & \\
\hline & Saf\&Sec 3 & .770 & & & \\
\hline \multirow{3}{*}{$\begin{array}{l}\text { Appearance and } \\
\text { presentation } \\
\text { (App\&Pre) }\end{array}$} & App\&Pres1 & .816 & \multirow[t]{3}{*}{.708} & \multirow[t]{3}{*}{0.8522} & \multirow[t]{3}{*}{0.6577} \\
\hline & App\& Pres2 & .814 & & & \\
\hline & App\&Pres3 & .803 & & & \\
\hline \multirow{3}{*}{$\begin{array}{l}\text { Attitudes Towards } \\
\text { UGC (AttUGC) }\end{array}$} & AttUGC1 & .827 & \multirow[t]{3}{*}{.713} & \multirow[t]{3}{*}{0.8265} & \multirow[t]{3}{*}{0.6141} \\
\hline & AttUGC2 & .791 & & & \\
\hline & AttUGC3 & .730 & & & \\
\hline \multirow{2}{*}{$\begin{array}{c}\text { Behavioral } \\
\text { intentions towards } \\
\text { hotel booking } \\
\text { (Behv) }\end{array}$} & Behav1 & .881 & \multirow[t]{2}{*}{.755} & \multirow[t]{2}{*}{0.8739} & \multirow[t]{2}{*}{0.5174} \\
\hline & Behav2 & .881 & & & \\
\hline
\end{tabular}

Note: SPSS results

(Brown, 2014; Hair Jr et al., 2010). The convergent validity including factor loading, Cronbach's Alpha, construct reliability (CR), and average variance extracted (AVE) summary is shown in table 3 . It is evident that this study meets all requirements of convergent validity.

Before applying multivariate analysis for mediation through SEM, the inter-construct correlation was also calculated to assess the relationship between constructs. The correlation coefficient up to \pm .1 represents a small effect, \pm .3 a medium and \pm .5 or greater represents large effect (Field, 2009). The table 4 shows a significant moderate relationship between web functionality and information content and quality $\left(\mathrm{r}=.344^{* *}, \mathrm{p}<.05\right)$, safety and security $\left(\mathrm{r}=.383^{* *}, \mathrm{p}<.05\right)$, appearance and presentation $\left(\mathrm{r}=.385^{* *}, \mathrm{p}<.05\right)$, attitude towards UGC $\left(\mathrm{r}=.468^{* *}, \mathrm{p}<.05\right)$, and behavior towards hotel booking $\left(\mathrm{r}=.473^{* *}, \mathrm{p}<.05\right)$. The relationship between safety and security is found significantly moderate between content and quality $\left(\mathrm{r}=.408^{* *}, \mathrm{p}<.05\right)$, appearance and presentation $\left(\mathrm{r}=.432^{* *}, \mathrm{p}<.05\right)$, attitude towards UGC adoption $\left(\mathrm{r}=.401^{* *}, \mathrm{p}<.05\right)$ and behavior towards hotel booking $\left(r=.415^{* *}, p<.05\right)$. However, the relationship between appearance and presentation and safety and security of travelling website found significantly strong $\left(r=.700^{*}, \mathrm{p}<.05\right)$ and it shows that presentation and appearance of the travelling website is strongly related to the perception of safety and security which is an important dimension of website quality. The relationship between appearance and presentation and attitude towards UGC adoption is found significantly moderate $\left(\mathrm{r}=.352^{* *}, \mathrm{p}<.05\right)$ and behavior towards booking is also significantly moderate $(\mathrm{r}=.400, \mathrm{p}<.05)$. Appearance and presentation showed significant, positive moderate relationship with attitude towards $\mathrm{UGC}\left(\mathrm{r}=.388^{* *}, \mathrm{p}<.05\right)$ and behavior towards hotel 
Table 4: Inter-Construct Correlations

\begin{tabular}{|c|c|c|c|c|c|c|}
\hline Constructs & Webf & Infoqual & Saf\&Sec & App\&Pre & AttUGC & Behv \\
\hline Web functionality & 1 & & & & & \\
\hline $\begin{array}{l}\text { Information Content and } \\
\text { Quality }\end{array}$ & $.344^{* *}$ & 1 & & & & \\
\hline Safety and Security & $.383^{* *}$ & $.408^{* *}$ & 1 & & & \\
\hline $\begin{array}{c}\text { Appearance and Presen- } \\
\text { tation }\end{array}$ & $.385^{* *}$ & $.432^{* *}$ & $.700^{* *}$ & 1 & & \\
\hline $\begin{array}{c}\text { Attitudes Towards UGC } \\
\text { Adoption }\end{array}$ & $.468^{* *}$ & $.401^{* *}$ & $.352^{* *}$ & $.388^{* *}$ & 1 & \\
\hline $\begin{array}{l}\text { Behavioral intentions } \\
\text { towards hotel booking }\end{array}$ & $.473^{* *}$ & $.415^{* *}$ & $.400^{* *}$ & $.414^{* *}$ & $.533^{* *}$ & 1 \\
\hline
\end{tabular}

${ }^{* *}$. Correlation is significant at the 0.01 level (2-tailed).

booking $\left(\mathrm{r}=.414^{* *}, \mathrm{p}<.05\right)$. The attitude towards UGC and behavior towards hotel booking is significant and strong $(\mathrm{r}=.533, \mathrm{p}<.05)$. As inter-construct correlation is found significant, positive and moderate thus qualify the assumptions of plugging into one theoretical model for SEM.

For data analysis, Structural Equation Modelling (SEM) is applied to multivariate data analysis. This study has four independent variables including web functionality, information content and quality, safety and security and appearance and presentation to measure the service quality of the travelling agency website. Attitude towards UGC is added as an independent and mediator variable and behavior towards hotel booking is introduced as the dependent variable. SEM is applied to test the theoretical model i.e. service quality of the travelling company website built the attitude towards UGC adoption that affects behavior towards hotel booking. In other words, better service quality provided by travelling company develop a positive attitude towards reviewing UGC and that effects the behavior towards hotels booking. AMOS V.22 was used to test the hypothesis. For the structural model, the goodness-of-fit of the model is testified with multiple measures. The chi-square measures the difference between observed and estimated covariance and the smaller value is more desirable. Good-offit index (GFI) threshold is $\geq 0.99$ whereas the root means square residual (RMSEA)

Table 5: Goodness-of-Fit Indices of SEM

\begin{tabular}{|c|c|c|}
\hline Goodness of Fit & SEM Values & Threshold \\
\hline Chi-square/degree of freedom & $.801 / 3$ & $\leq 3$ \\
\hline Comparative Fit Index (CFI) & 1.00 & $\geq .9$ \\
\hline
\end{tabular}




\begin{tabular}{|c|c|c|}
\hline Normed Fit Index (NFI) & .999 & $\geq .9$ \\
\hline P-Close & .949 & \\
\hline Root Mean Square of Approximation (RMSEA) & .000 & $\leq .10$ \\
\hline Adjusted goodness-of-fit index (AGFI) & .994 & $>.95$ \\
\hline Good-of-fit index (GFI) & .999 & $\geq 0.99$ \\
\hline
\end{tabular}

Reference for reporting (Schreiber, Nora, Stage, Barlow, \& King, 2006)

threshold is $<0.10$. The P-close (test of close fit) threshold is $>0.9$. Normed-fit-index threshold $=1$ for a perfect model and adjusted goodness-of-fit index (AGFI) threshold is > .95 (Brown, 2014; Byrne, 2016; Hair Jr et al., 2010). The goodness-of-fit indices are given Table 5 that demonstrates that the theoretical model adopted for the underlying study is a good fit.

Table 6 showed the direct and indirect effects of the model which are assumed to be more meaningful. The direct effect of web functionality on attitude is found as $.315(\mathrm{p}<.05)$ and the effect is significant thus it is inferred the travel customer's attitude towards UGC is influenced by the functionality of travelling company website. Likewise, the information content and quality showed an effect size of .228 ( $p<.05)$ and appearance and presentation also showed the effect size of .142 ( $\mathrm{p}<.05)$ exhibiting the influence on attitude towards UGC. Surprisingly, in the case of Pakistani travellers, safety and security which is the most commonly reported measure in website quality literature are found insignificant with an effect size of .076. This result is quite contradictory to present literature. The behavior towards hotel booking is very much influenced by the attitude towards UGC thus it is inferred that a positive or negative attitude towards UGC affect the actual purchase i.e. booking a hotel. As mentioned

Table 6: Direct and Indirect Effect of Serial Multiple Mediator Model

\begin{tabular}{|c|c|c|}
\hline Direct effect & Effect Size & P \\
\hline Webf $\rightarrow$ AttUGC & .315 & ${ }^{* * *}$ \\
\hline Infoqual $\rightarrow$ AttUGC & .228 & ${ }^{* * *}$ \\
\hline Saf\&Sec $\rightarrow$ AttUGC & .076 & .156 \\
\hline App\&Pre $\rightarrow$ AttUGC & .142 & .010 \\
\hline AttUGC $\rightarrow$ Behv & 1.122 & ${ }^{* * *}$ \\
\hline Indirect effects summary & Effect Size & \\
\hline Webf $\rightarrow$ AttUGC $\rightarrow$ Behv & .353 & \\
\hline Infoqual $\rightarrow$ AttUGC $\rightarrow$ Behv & .256 & \\
\hline Saf\&Sec $\rightarrow$ AttUGC $\rightarrow$ Behv & .086 & \\
\hline App\&Pre $\rightarrow$ AttUGC $\rightarrow$ Behv & .159 & \\
\hline
\end{tabular}

SPSS output 
in the model, the attitude towards UGC is introduced as a mediator between web functionality, information content and quality, safety and security, appearance and presentation, and behavior toward hotel booking. SEM results showed that the indirect effect sizes between web functionality, information content and quality, safety and security, appearance and presentation and behavior towards hotel booking mediated by the attitude towards UGC and the result showed augmented indirect size effects.

The hypothesis testing results are summarized in table 7.

Table 7: Hypothesis Testing Result Summary

\begin{tabular}{|c|c|}
\hline Hypothesis & Result \\
\hline $\begin{array}{l}\text { H1: Website functionality of travelling company website has a positive } \\
\text { impact on attitude towards UGC }\end{array}$ & Supported \\
\hline $\begin{array}{l}\text { H2: Information content } \& \text { quality of travelling company website has a } \\
\text { positive impact on attitude towards UGC }\end{array}$ & Supported \\
\hline $\begin{array}{l}\text { H3: Safety and security of travelling company has a positive impact on } \\
\text { attitude towards UGC }\end{array}$ & \\
\hline $\begin{array}{l}\text { H4: Appearance and presentation of travelling company website has a } \\
\text { positive impact on attitude towards UGC }\end{array}$ & Supported \\
\hline $\begin{array}{l}\text { H5: The relationship between web functionality, information content } \\
\& \text { quality, safety } \& \text { security, appearance and presentation and behavior } \\
\text { towards hotel booking is mediated through attitude towards UCU }\end{array}$ & Supported \\
\hline
\end{tabular}

\section{Discussion}

Analysis of the data has uncovered quite several of interesting facts about the problem at hand. The results showed that the website service quality is very critical for all type of travellers including young, middle-income, business, leisure and family travellers either travelling frequently or rarely. The kind of UGC on travelling websites is accessible in the form of reviews of travellers, traveller's virtual communities, travellers answering traveller's queries, destination and hotel rating. The volume of UGC in all travelling website is massive thus its role in shaping the attitude and the actual purchase i.e. hotel booking must not leave unobserved especially in Pakistani context where such studies are least conducted so far. The selected respondents of the underlying study are mostly young and middle-income travellers thus more they are concerned with the budget of their travel. The internet has become of the most used source of information (Henson, Guy, \& Dotson, 2015; Parasuraman et al., 1994) thus practitioners need to realize the role of website quality in determining the attitude towards UGC and behavior of hotel booking. The direct effect of website 
functionality is found one the leading predictor of attitude towards $\operatorname{UGC}(.315, \mathrm{p}<.001)$ for Pakistani travellers and SEM results are not found different from literature. The literature also supports the fact that website functionality is the leading predictor of customer satisfaction while using online travelling websites. Thus, the $\mathrm{H}_{1}$ i.e. website functionality of the travelling company has a positive impact on attitude towards UGC adoption is accepted. In Pakistan, where most of the internet users are very young, they prefer internet browsing. Website functionality facilitates the travellers to spend more time on the website thus the chances of reading more UGC and booking a hotel increase. Functionality of website reduces efforts of internet users and enables the information searching. The second best predictor of attitude towards of adoption of UGC for Pakistani travellers is information content and quality $(.228, \mathrm{p}<.001)$ and the literature also support the same construct as the second best predictor of customer satisfaction (Fu Tsang et al., 2010; Samsi et al., 2016). Thus, it is inferred that $\mathrm{H}_{2}$ i.e. information content \& quality of travelling website has a positive impact on attitude towards adoption of UGC in the context of Pakistan is also accepted. It is obvious that UGC is presumed as the source of information thus the travellers, as compared to commercialized AGC, prefer UGC. The UGC quality is usually exhibited in well written shared experiences and pictures. Furthermore, it is believed that hotels can work with limited number of influencers but larger public opinion pool cannot be manipulated.

The traveller attitude towards UGC adoption in Pakistan is not dissimilar to international travellers in case of web functionality and information content and quality. The most surprising result with reference to Pakistani travellers is observed with reference to the safety and security of travelling websites. Safety and security is the most common and frequently adopted measure for website quality (Kim, Kim, \& Heo, 2016; Madu \& Madu, 2002; Parasuraman et al., 2005; Park et al., 2007) but it is found as an insignificant weak predictor in case of Pakistani travellers (.076, $\mathrm{p}>$.05). Several studies have identified that perceived risk is negatively associated with online purchase intentions (Hong, 2015; Pappas, 2016). In the present study case, it is anticipated that if Pakistani travellers assume high risk i.e. lack and safety and security of information on travelling website, they will exhibit a negative attitude towards reading and trusting UGC on such website. So far, the results are negating such an assumption thus the $\mathrm{H}_{3}$ i.e. safety and security of travelling website has a positive impact on the attitude towards adoption of UGC is not accepted in Pakistani context. So far, the cybercrime rate in Pakistan is minutest as compared to developed countries thus there is some plausible explanation of such peculiar results. It is also inferred that the internet users are not well aware of the misuse of information. Website appearance and presentation is found third best predictor of attitude towards UGC adoption $(.142, \mathrm{p}=.010)$ in case of Pakistani travellers that confirmed the acceptance of $\mathrm{H}_{4}$ i.e. 
appearance and presentation of travelling company website has a positive impact on attitude towards UGC adoption. As mentioned earlier, the aim of this study is to find the impact of the direct and indirect effect of website quality of travelling companies on attitude towards UGC adoption and hotel booking behavior, thus, $\mathrm{H}_{5}$ was developed and tested. The indirect effect of website functionality on hotel booking behavior is mediated by the attitude towards UGC, as a result, it is inferred that website functionality brings a positive attitude of travel customers towards UGC that could result in actual sales. Likewise, the relationship between information content and quality on hotel booking behavior is mediated through the attitude towards UGC. The results support the argument that information content and quality is contingent on the attitude of travel customers towards UGC adoption for hotel booking. The dimension of safety and security for Pakistani travel customers' needs further investigation. Though the indirect impact of safety and security is observed significant on hotel booking behavior, still the effect size is lesser as compared to other dimensions. The appearance and presentation of the website also exhibit an indirect effect on booking behavior mediated by the attitude towards UGC. Hence, it is assumed the website functionality, information content and quality, safety and security, appearance presentation of travelling website and booking behavior is highly influenced by the travel customer attitude towards UGC.

\section{Conclusion}

With the increasing number of young people around the world, travelling is becoming part of their regular routine. Younger generation is more open towards travelling, gives importance to the user generated content and believes that technology is the answer. In this study, the objective was to uncover impact of website service quality on the attitude towards UGC and hotel booking behavior which is found significant and supported by the literature. The surprising element was an insignificant and weak indirect effect of safety and security in case of Pakistani customers that brings a new debate. The cybercrime rate statistics in the world need to be included to explain this contradictory observation in the context of Pakistan. According to Statista ${ }^{5}$, USA, China, Germany, Great Britain, Brazil , Japan and India are found more vulnerable countries for cybercrime and that these statistics reveal the issues of safety and security of websites in these countries. In Pakistan, internet users have less exposure and understanding of cybercrime and cybercrime bill was passed in 2015 by the National Assembly of Pakistan (Khan, 2017). Though Pakistan has seen a rise in the cybercrime rate (The Nation, 2016) still in case of UGC, it is not considered as a serious threat by Pakistani travellers till today. The present study reveals the fact that most of the travellers are searching travel information for finding

5 https://www.statista.com/statistics/194133/cybercrime-rate-in-selected-countries/ 
multiple alternates on such websites hence the actual purchase i.e. booking a hotel might not be best predicted by safety and security. The travelling agencies must not be trapped by over-reliance on website quality for actual digital sales. Such websites must also focus on developing the positive attitude of customers towards UGC otherwise that would be no value of such humongous content on the websites. More inclination towards UGC possibly will bring more digital sales.

\section{Managerial Implications}

Technology is only going to get bigger and more penetrating in Pakistani society. It is crucial that travelling companies realise this fact, and address the issues pertaining to Pakistani users on an immediate basis. This study gives ways to the managers of the local, as well as international travelling organizations to consider Pakistani travellers more informed, technology oriented and financially capable. Majority of the population is under the age of 30 years that are open to travel on regular basis. They seek feedback from fellow travellers by using UGC on the websites. Website is always the first step in the hotel booking process where a user collects the information. By understanding and formulating a website strategy based on results of this study, managers are more likely to gain attention of Pakistani travellers that are leaving marks in global travel. For the managers of all such travelling websites, it must be a matter of concern that their users from the region of Pakistan are least aware of safety and security and might get involved in any mal activity unintentionally. It is also unanticipated to observe the least concern about the safety and security of the website from the travellers who are mostly travelling with their families as $61.9 \%$ respondents of this study are travelling with their families. It requires educating travellers about safety and security of their information. It will also increase their trust and reliance on UGC and organizations related information provided on the website.

\section{Limitation and Future Direction}

Although this study is contemporary and deals with the current issue in a very relevant industry to the Pakistani population, it is observed that further studies should build on the findings of the present study. This study deals with the booking intentions, rather than the actual bookings of the hotel. Future studies should focus on conducting and finding out the factors associated with the actual process of hotel booking. Furthermore, present study has a mix of demographics. It is suggested that future research should focus mainly on the younger Pakistani population (Millennial) as they are more technology friendly and can become a good source of business development for travelling organizations. By uncovering their consumption patterns and habits, academicians can suggest insights to the travelling business owners that can improve the efficiency and effectiveness of their operations while dealing with the 
young and technology loving individuals and same is marked as academic contribution for underlying study. The moderating and/or mediating role of demographics in explaining the attitude towards UGC and hotel booking is also strongly recommended for future studies.

\section{References}

Abou-Shouk, M. A., \& Khalifa, G. S. (2017). The influence of website quality dimensions on e-purchasing behaviour and e-loyalty: a comparative study of Egyptian travel agents and hotels. Journal of Travel Eु Tourism Marketing, 34(5), 308-623.

Agag, G. M., \& El-Masry, A. A. (2017). Why do consumers trust online travel websites? Drivers and outcomes of consumer trust toward online travel websites. Journal of Travel Research, 56(3), 347-369.

Ali, F. (2016). Hotel website quality, perceived flow, customer satisfaction and purchase intention. Journal of Hospitality and Tourism Technology, 7(2), 213-228.

Amaral, F., Tiago, T., \& Tiago, F. (2014). User-generated content: Tourists' profiles on Tripadvisor. International Journal of Strategic Innovative Marketing, 1(3), 137-145.

Bauer, H. H., Falk, T., \& Hammerschmidt, M. (2006). eTransQual: A transaction process-based approach for capturing service quality in online shopping. Journal of Business Research, 59(7), 866-875.

Bodewes, D. (2016). Book review of the new digital shoreline: How web 2.0 and millennials are revolutionizing higher education. Open Praxis, 8(1), 73-74.

Brown, T. A. (2014). Confirmatory factor analysis for applied research: Guilford Publications.

Byrne, B. M. (2016). Structural equation modeling with AMOS: Basic concepts, applications, and programming: Routledge.

Cheong, H. J., \& Morrison, M. A. (2013). Consumers' reliance on product information and recommendations found in UGC. Journal of Interactive Advertising, 8(2), 38-49.

Chuang, H.-M., Chen, Y.-S., Lin, C.-Y., \& Yu, P.-C. (2016). Featuring the e-service quality of online website from a varied perspective. Human-centric Computing and Information Sciences, 6(1), 6.

Chung, J. Y., \& Buhalis, D. (2008). Web 2.0: A study of online travel community. Information and communication technologies in tourism 2008, 70-81.

Constantinides, E., \& Fountain, S. J. (2008). Web 2.0: Conceptual foundations and marketing issues. Journal of direct, data and digital marketing practice, 9(3), 231-244.

Cox, C., Burgess, S., Sellitto, C., \& Buultjens, J. (2009). The role of user-generated content in tourists' travel planning behavior. Journal of Hospitality Marketing $\mathcal{E}$ Management, 18(8), 743-764.

Daugherty, T., Eastin, M. S., \& Bright, L. (2008). Exploring consumer motivations for creating user-generated content. Journal of interactive advertising, 8(2), 16-25. 
Dedeke, A. N. (2016). Travel web-site design: Information task-fit, service quality and purchase intention. Tourism management, 54, 541-554.

Dellarocas, C. (2003). The digitization of word of mouth: Promise and challenges of online feedback mechanisms. Management science, 49(10), 1407-1424.

Field, A. (2009). Discovering statistics using SPSS: Sage publications.

Fu Tsang, N. K., Lai, M. T., \& Law, R. (2010). Measuring e-service quality for online travel agencies. Journal of Travel \& Tourism Marketing, 27(3), 306-323.

Goswami, S. (2013). Measuring customer satisfaction on webqual dimension for online banking: An empirical study. Paradigm, 17(1), 25-36.

Hair Jr, J., Black, W., Babin, B., \& Anderson, R. (2010). Multivariate data analysis: A global perspective. New Jersey, USA: Pearson Education.

Harris, A. L., \& Rea, A. (2019). Web 2.0 and virtual world technologies: A growing impact on IS education. Journal of information systems education, 20(2), 137-144.

Henson, J. N., Guy, B. S., \& Dotson, M. J. (2015). Should I stay or should I go? Motivators, decision factors, and information sources influencing those predisposed to medical tourism. International Journal of Healthcare Management, 8(1), 4-14.

Hong, I. B. (2015). Understanding the consumer's online merchant selection process: The roles of product involvement, perceived risk, and trust expectation. International Journal of Information Management, 35(3), 322-336.

Huang, C. D., Goo, J., Nam, K., \& Yoo, C. W. (2017). Smart tourism technologies in travel planning: The role of exploration and exploitation. Information $\mathcal{E}$ Management, 54(6), 757-770.

Hughes, K., Wang, J., \& Shu, M. (2015). Exploring the travel patterns, preferences and recommendations of Chinese university students living in Australia. Journal of Hospitality and Tourism Management, $23,12-22$.

Internet World Stats. (2017). Internet usage statistics: The internet big picture. Available at: http://www. internetworldstats.com/stats.htm

Jiang, L., Jun, M., \& Yang, Z. (2016). Customer-perceived value and loyalty: how do key service quality dimensions matter in the context of B2C e-commerce? Service Business, 10(2), 301-317.

Kay, C. (2017). As terror attacks recede, tourism in pakistan starts to thrive. Available at: https://www. bloomberg.com/news/articles/2017-09-27/as-terror-attacks-recede-tourism-in-pakistan-starts-tothrive

Kaynama, S. A., \& Black, C. I. (2000). A proposal to assess the service quality of online travel agencies: An exploratory study. Journal of professional services marketing, 21(1), 63-88. 
Khan, R. (2017). Controversial cyber crime bill approved by NA, Dawn. Retrieved from https://www. dawn.com/news/1251853

Kim, B., Kim, S., \& Heo, C. Y. (2016). Analysis of satisfiers and dissatisfiers in online hotel reviews on social media. International Journal of Contemporary Hospitality Management, 28(9), 1915-1936.

Ladhari, R., \& Michaud, M. (2015). eWOM effects on hotel booking intentions, attitudes, trust, and website perceptions. International Journal of Hospitality Management, 46, 36-45.

Leech, N. L., Barrett, K. C., \& Morgan, G. A. (2005). SPSS for intermediate statistics: Use and interpretation: Psychology Press.

Lien, C.-H., Wen, M.-J., Huang, L.-C., \& Wu, K.-L. (2015). Online hotel booking: The effects of brand image, price, trust and value on purchase intentions. Asia Pacific Management Review, 20(4), 210-218.

Litvin, S. W., Goldsmith, R. E., \& Pan, B. (2008). Electronic word-of-mouth in hospitality and tourism management. Tourism management, 29(3), 458-468.

Loiacono, E. T., Watson, R. T., \& Goodhue, D. (2002). WebQual: A measure of web site quality. In K. Evans \& L. Scheer (Eds.), Proceedings of the AMA Winter Educator's Conference. (pp. 432-438). Chicago: American Marketing Association

Madden, T. J., Ellen, P. S., \& Ajzen, I. (1992). A comparison of the theory of planned behavior and the theory of reasoned action. Personality and Social Psychology Bulletin, 18(1), 3-9.

Madu, C. N., \& Madu, A. A. (2002). Dimensions of e-quality. International Journal of Quality $\mathcal{E}$ reliability management, 19(3), 246-258.

Muthén, L. K., \& Muthén, B. O. (2002). How to use a Monte Carlo study to decide on sample size and determine power. Structural Equation Modeling, 9(4), 599-620.

Netemeyer, R., Ryn, M. V., \& Ajzen, I. (1991). The theory of planned behavior. Orgnizational Behavior and Human Decision Processes, 50, 179-211.

Newman, R., Chang, V., Walters, R. J., \& Wills, G. B. (2016). Web 2.0-The past and the future. International Journal of Information Management, 36(4), 591-598.

Nusair, K. (2016). eWOM behavior in social networking websites: An empirical investigation of antecedents. Paper presented at the GAI International Academic Conferences Proceedings.

O’Reilly, T. (2005). Web 2.0: Compact definition? Available at: http://radar.oreilly.com/archives/2005/10/ web-20- compact-definition.html

Olimpia, G. E. S., Darío, G. H., Adriana, M. M. R., Verónica, G. G., \& Yolanda, T. F. (2016). Expectations and perspectives of users with the screening program for cervical cancer. Open Journal of Nursing, 6(8), 565-572.

Pappas, N. (2016). Marketing strategies, perceived risks, and consumer trust in online buying behaviour. 
Journal of Retailing and Consumer Services, 29, 92-103.

Parasuraman, A., Berry, L. L., \& Zeithaml, V. A. (1991). Refinement and reassessment of the SERVQUAL scale. Journal of retailing, 67(4), 420.

Parasuraman, A., Zeithaml, V. A., \& Berry, L. L. (1985). A conceptual model of service quality and its implications for future research. the Journal of Marketing, 41-50.

Parasuraman, A., Zeithaml, V. A., \& Berry, L. L. (1988). Servqual: A multiple-item scale for measuring consumer perc. Journal of retailing, 64(1), 12.

Parasuraman, A., Zeithaml, V. A., \& Berry, L. L. (1994). Reassessment of expectations as a comparison standard in measuring service quality: implications for further research. The Journal of Marketing, 111-124.

Parasuraman, A., Zeithaml, V. A., \& Malhotra, A. (2005). ES-QUAL: A multiple-item scale for assessing electronic service quality. Journal of service research, 7(3), 213-233.

Park, Y. A., Gretzel, U., \& Sirakaya-Turk, E. (2007). Measuring web site quality for online travel agencies. Journal of Travel $\mathbb{E}$ Tourism Marketing, 23(1), 15-30.

Razak, N. S. A., Ahmad, A. H., \& Marimuthu, M. (2016). The effect of website quality on repurchase intention in travel agency's website in malaysia. Paper presented at the First International Conference on Advanced Business and Social Sciences. ISBN.

Samsi, M., BT, S. Z., Jamaluddin, H., Noor, M., Shabrina, A., Mohd, H., . . Abdullah, S. (2016). Information quality, usefulness and information satisfaction in islamic e-tourism websites. Journal of Theoretical Eु Applied Information Technology, 89(2), 450-460.

Santos, J. (2003). E-service quality: a model of virtual service quality dimensions. Managing Service Quality: An International Journal, 13(3), 233-246.

Schreiber, J. B., Nora, A., Stage, F. K., Barlow, E. A., \& King, J. (2006). Reporting structural equation modeling and confirmatory factor analysis results: A review. The Journal of educational research, 99(6), 323-338.

Sigala, M., Lockwood, A., \& Jones, P. (2001). Strategic implementation and IT: Gaining competitive advantage from the hotel reservations process. International Journal of Contemporary Hospitality Management, 13(7), 364-371.

Sigala, M., \& Sakellaridis, O. (2004). The impact of users' cultural characteristics on e-service quality: Implications for globalising tourism and hospitality websites. Available at: https://www.researchgate.net/ profile/Marianna_Sigala/publication/228408546_The_Impact_of_Users'_Cultural_Characteristics_on_E-Service_Quality_Implications_for_Globalising_Tourism_and_Hospitality_Websites/ links/02e7e526a1f555ee4a000000.pdf

Sun, P., Cárdenas, D. A., \& Harrill, R. (2016). Chinese customers' evaluation of travel website quality: 
A decision-tree analysis. Journal of Hospitality Marketing $\mathcal{E}$ Management, 25(4), 476-497.

Susilowati, C., \& Sugandini, D. (2018). Perceived value, e-word-of-mouth, traditional word-of-mouth, and perceived quality to destination image of vacation tourists. Review of Integrative Business and Economics Research, 7, 312-321.

The Nation. (2016). Seriousness towards cyber crime laws in Pakistan, The Nation,. Retrieved from https:// nation.com.pk/22-Aug-2016/seriousness-towards-cyber-crime-laws-in-pakistan

Tribune. (2019). Pakistan expects foreign investment in tourism sector, Tribune.

VanVoorhis, C. W., \& Morgan, B. L. (2007). Understanding power and rules of thumb for determining sample sizes. Tutorials in Quantitative Methods for Psychology, 3(2), 43-50.

Wolf, E. J., Harrington, K. M., Clark, S. L., \& Miller, M. W. (2013). Sample size requirements for structural equation models: An evaluation of power, bias, and solution propriety. Educational and Psychological Measurement, 73(6), 913-934.

Xiang, Z., \& Gretzel, U. (2010). Role of social media in online travel information search. Tourism management, 31(2), 179-188.

Yoo, B., \& Donthu, N. (2001). Developing a scale to measure the perceived quality of an Internet shopping site (SITEQUAL). Quarterly Journal of Electronic Commerce, 2(1), 31-45.

Zhu, F., \& Zhang, X. (2006). The influence of online consumer reviews on the demand for experience goods: The case of video games. Available at: https://pdfs.semanticscholar.org/61e4/4fd3c383a73a7157b5fdaaf0771a6249b79f.pdf 
